\title{
Coastal marsh soils in Poland: characteristics and problems of classification
}

\begin{abstract}
This paper presents the current state of knowledge concerning the genesis, properties and taxonomic position of soils developed from marine and marine-alluvial sediments in Poland, called "marsh soils". They have not as yet been identified in the fifth edition of the Polish Soil Classification (2011). However, the author's results demonstrate that, despite occupying only a small area along the Polish Baltic coast, these soils clearly show a distinct typological specificity. This confirms the need to include the marsh soils in the Polish classification system. Therefore, the creation a separate unit within the order of weakly-developed soils was proposed. This comprehensive proposal was fully compatible with the quantitative-genetic approach used in the fifth edition. However, this proposal may not be optimal in the context of a substantial modification of the Polish classification system, e.g. by the introduction of completely quantitative hierarchical key. Because of the close taxonomic relationships between marsh, alluvial and gley soils, it seems necessary to discuss the approach used in the current edition of the WRB classification (2015).
\end{abstract}

Key words: coastal marsh soils, Baltic Sea, Polish Soil Classification, WRB

\section{INTRODUCTION}

Coastal marshes are transitional habitats between terrestrial and aquatic systems where the ground water table is usually high, or the land is covered by shallow water tidally or seasonally. They include plants that are adapted to salty or brackish water conditions (Thayer et al. 2003). However, the term can also be used in a somewhat narrower sense, e.g. for soils formed from layers of sea sediments in areas subject to sea transgressions and regressions (Polish Soil Classification 1974), or soils developed from sediments deposited under natural conditions in tidal areas with high daily water-table fluctuations (Ad-hoc-Arbeitsgruppe Boden 2005). Due to the nature of the Baltic Sea, wetlands and soils along its shore are usually described as brackish (Dijkema 1990, van der Graaf et al. 2007, Hulisz 2013). They may be flooded occasionally during high water levels and storms, including seawater penetration into rivers (backwater). In previous editions of the Polish Soil Classification $(1974,1989)$ these soils were also called "marsh soils" (in Polish: marsze) or "marsh alluvial soils" (in Polish: mady morskie).

This review paper provides a comprehensive identification of the marsh soils based on the previous published findings of the author (Hulisz et al. 2012, Hulisz 2013, Hulisz 2014, Hulisz et al. 2015). These soils, as is also the case with cliff naspas (in Polish: naspy przyklifowe; Prusinkiewicz 1971) and acid sulphate soils (Pracz 1989), are still under-researched soils in Poland, and hence have not been distinguished in the current edition of the Polish Soil Classification (2011). Therefore, it seems necessary to discuss the problems relating to the nomenclature and taxonomic position of marsh soils, and, finally, to introduce a new unit dedicated to such soils in the next edition of the Polish soil classification system.

\section{MARSH SOIL FORMATION IN POLAND}

The Polish coastal zone is dominated by cliffs and dunes (Kostrzewski and Musielak 2008), therefore the formation of marsh soils is limited to estuaries, lagoons or deltas which constitute small areas of the coastal plains. The parent materials of these soils can be both marine and marine-alluvial sediments. As with alluvial soils (in Polish: mady; Dąbkowska-Naskręt 1990; Malinowski 2012, Michalski 2015), the development of coastal marsh soils is mostly affected by geogenetic (lithogenic) processes related to sedimentation of mineral material, which result in the development of a stratified soil profile. However, sedimentation of deposits takes place not in the terrestrial environment, but in the marine-terrestrial (marginalmarine) environment, with variable input of allochthonous and autochthonous organic matter. Moreover, other processes such as gleyzation, salinization, 
sulphide accumulation, peat sedimentation, etc., may occur simultaneously or secondarily (Hulisz 2013). Soil formation in coastal areas with a combination of geogenetic processes is known as geo-pedogenesis (Schroeder and Brümmer 1969, Giani 1992). The rate and the nature of soil forming processes depend on landscape positions: initial soils are typical for the most dynamic environments, i.e. beaches and river mouths, whereas semi-mature soils typify other locations. Some soils may show a specific spatial distribution pattern within a relatively short distance from the waterline, which can be referred as a hydro-toposequence (Hulisz 2013, 2014).

The marsh soils in Poland are distributed across the following southern Baltic Sea areas (Fig. 1): Szczecin Lagoon (the reverse delta of the Swina River), Kamień Pomorski Lagoon, Puck Lagoon, Vistula River delta, and Vistula Lagoon, as well as along the shoreline of some coastal lakes (e.g., Krzyszowski 1952, Witek 1965, Pracz 1989, Niedźwiecki et al. 2002, Hulisz 2013). Some of these soils have developed under strong human impact, especially as a result of hydrotechnical works (e.g. construction of river channels, floodbanks and breakwaters). Such soils can be found in the artificial mouth of the Vistula River (Hulisz et al. 2015), the Marzęcino polder, the Vistula Lagoon (Baranowski 1962), the Karsiborska Kępa island and the Szczecin Lagoon (Hulisz 2013). As the study of marsh soils is still in progress, the total area has not yet been determined. However, there are some examples showing that individual marsh sites occupy rather small areas, i.e. about 315 ha in the Karsiborska Kępa island (Hulisz 2013), about 150 ha in the Vistula River delta (Witek 1965) and about 24 ha (with gleysols) at the mouth of the Vistula CrossCut (Hulisz et al. 2015).

\section{PROPERTIES OF MARSH SOILS}

Due to specificity of the Baltic Sea, the coastal marsh soils are not subject to regular sea tides, and have different properties than typical salt marsh soils from regions such as the North Sea (Giani 1992, Hulisz et al. 2013), Irish Sea (Huckle et al. 2004) or Pacific Coast (Shlyakhov and Kostenkov 1999).

Most profiles of the marsh soils in Poland contained evidence of sediment deposition in highly dynamic environments and are commonly affected by gleyic processes (Hulisz 2013). They were usually multilayered and rather shallow (up to tens of $\mathrm{cm}$ ). Sand with varying admixtures of silt and clay fractions dominated in carbonate-poor mineral horizons $\left(\mathrm{CaCO}_{3}\right.$ up to $5.6 \%, 0.2 \%$ on average; Table 1$)$. The content of total organic carbon (TOC) and total sulphur $\left(\mathrm{S}_{\mathrm{t}}\right)$ varied from 0.1 to $35 \%$ and from 0.01 to $2.82 \%$, respectively. In most cases the higher TOC and $\mathrm{S}_{t}$ values were related to the presence of shallowly-buried peat or mud horizons (Fig. 2). Some soils also have unique properties resulting from a constant inflow of allochthonous organic matter due to abrasion of the coastal peatland (e.g. in the Puck Lagoon; Hulisz et al. 2012, Hulisz 2013).

The accumulation of mineral forms of sulphur along with organic matter in reducing environments is a typical feature of marsh soils. Therefore, coastal plains usually have the greatest potential to generate

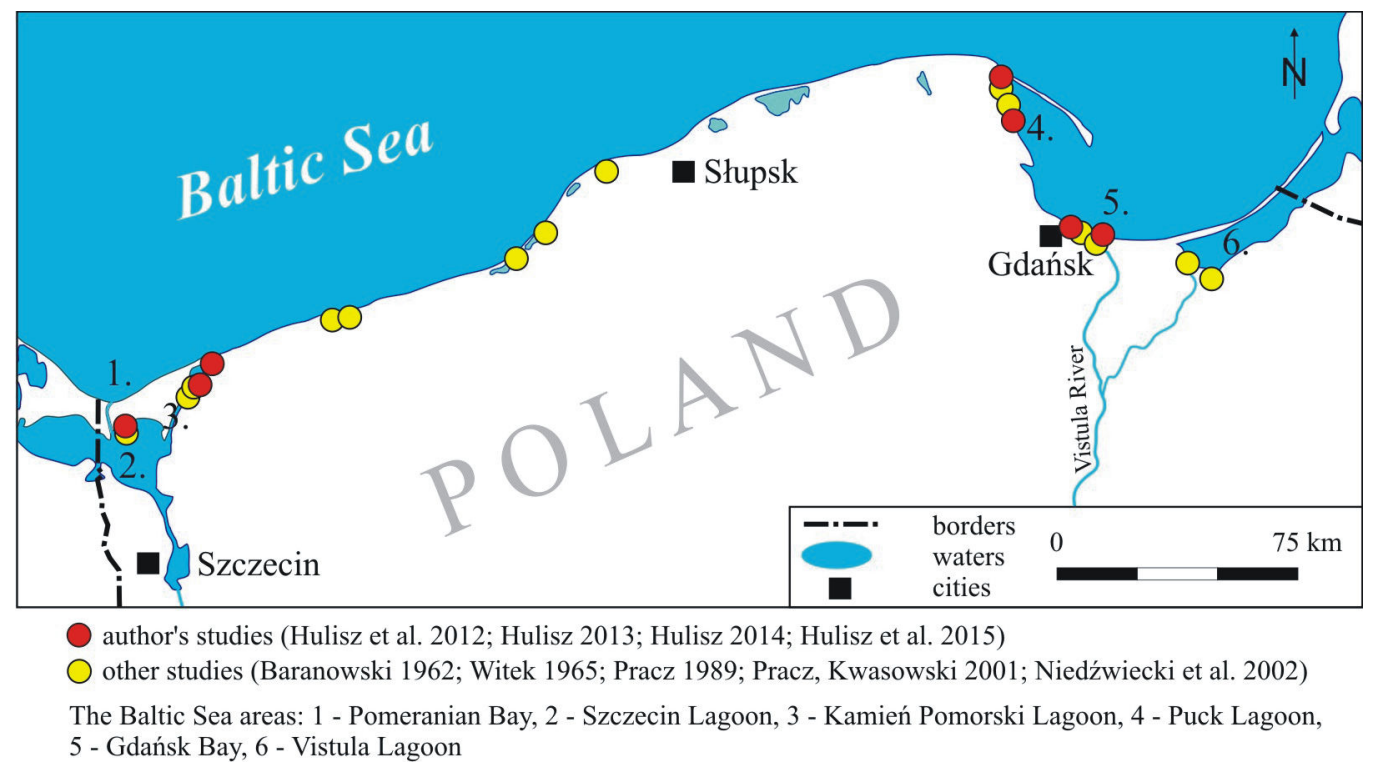

FIGURE 1. Distribution of coastal marsh soils in Poland 
TABLE 1. Characteristics of the studied coastal marsh soils $(\mathrm{n}=70)$ based on results by Hulisz (2013)

\begin{tabular}{|c|c|c|c|c|c|c|c|c|c|c|c|}
\hline \multirow[t]{2}{*}{ Parameter } & TOC & $\mathrm{S}_{\mathrm{t}}$ & $\mathrm{CaCO}_{3}{ }^{*}$ & \multirow[t]{2}{*}{$C: S$} & \multirow[t]{2}{*}{$\mathrm{rH}$} & \multirow[t]{2}{*}{$\mathrm{pH}_{\mathrm{a}}-\mathrm{pH}_{\mathrm{ox}}$} & \multirow{2}{*}{$\mathrm{pH}_{\mathrm{a}}-\mathrm{pH}_{\mathrm{pox}}$} & \multirow[t]{2}{*}{$\mathrm{pH}_{\mathrm{e}}$} & $\mathrm{EC}_{\mathrm{e}}$ & \multirow[t]{2}{*}{ SAR } & \multirow[t]{2}{*}{$\mathrm{Mg}: \mathrm{Ca}$} \\
\hline & {$[\%]$} & & & & & & & & {$\left[\mathrm{dS} \cdot \mathrm{m}^{-1}\right]$} & & \\
\hline Mean & 8.0 & 0.4 & 0.2 & 23 & 21 & 0.9 & 3.4 & 6.2 & 6.1 & 10 & 1.2 \\
\hline Minimum & 0.1 & $<0.1$ & 0.0 & 1 & 7 & 0.0 & 1.5 & 2.4 & 0.4 & 1 & 0.2 \\
\hline Maximum & 34.5 & 2.8 & 5.6 & 70 & 32 & 3.6 & 5.8 & 7.8 & 16.5 & 24 & 3.9 \\
\hline SD & 11.1 & 0.6 & 0.8 & 18 & 6 & 1.1 & 1.0 & 1.6 & 3.8 & 5 & 0.8 \\
\hline
\end{tabular}

${ }^{*}$ Found in some samples $(\mathrm{n}=20)$.

Explanations of symbols: TOC - total organic carbon, $\mathrm{S}_{\mathrm{t}}$ - total sulphur content, $\mathrm{rH}$ - index of the reducing power of a redox system (IUSS Working Group WRB 2015), $\mathrm{pH}_{\mathrm{a}}-\mathrm{pH}$ measurement in the field, $\mathrm{pH}_{\mathrm{ox}}-\mathrm{pH}$ measurement after incubation of soil samples under laboratory conditions within two months, $\mathrm{pH}_{\mathrm{pox}}-\mathrm{pH}$ measurement after oxidation with $30 \% \mathrm{H}_{2} \mathrm{O}_{2}, \mathrm{pH}_{\mathrm{e}}-\mathrm{pH}$ of saturation paste, EC $\mathrm{e}_{\mathrm{e}}-$ electrical conductivity of saturated paste extracts, SAR - sodium adsorption ratio of the saturated soil-paste extract, $\mathrm{SD}$ - standard deviation.

\section{Karsiborska Kępa} (Szczecin Lagoon)

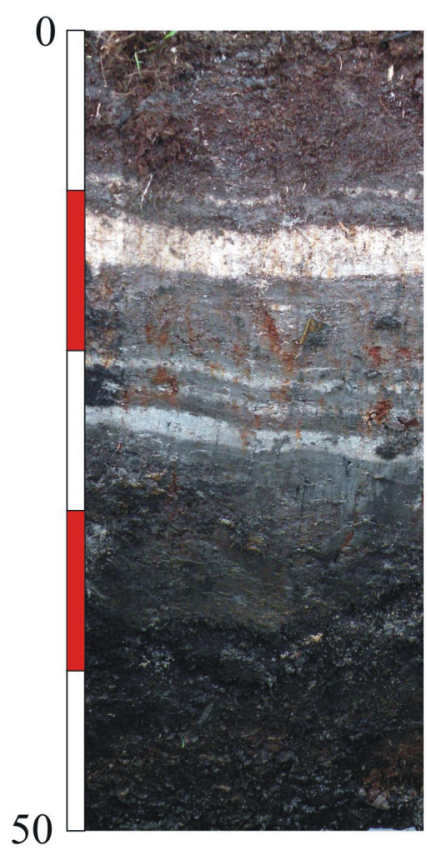

$[\mathrm{cm}]$

\section{Beka}

(Puck Lagoon)

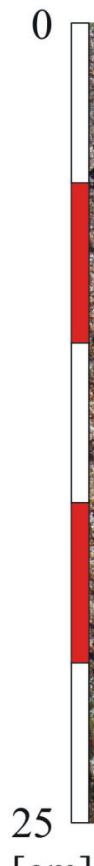

$[\mathrm{cm}]$

\section{Władysławowo \\ (Puck Lagoon)}

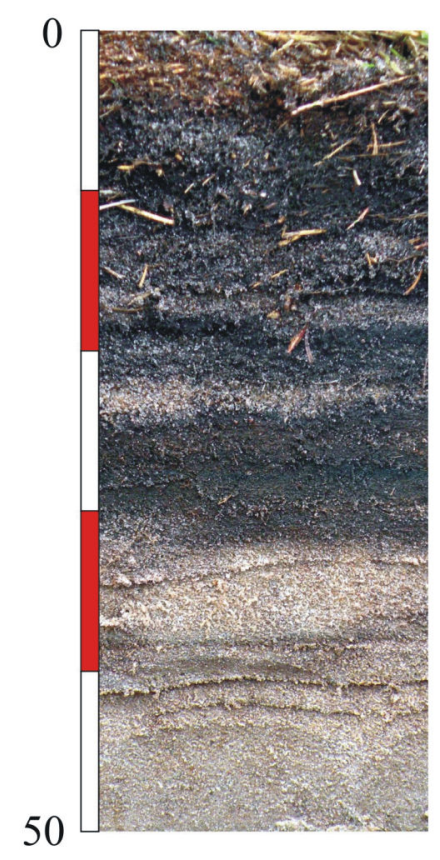

[cm]

FIGURE 2. Examples of marsh soil profiles

acid sulphate soils (Pracz 1989, Kwasowski 1999, Andriesse and van Mensvoort 2006). The oxidation of carbonate-poor materials rich in iron sulphides, (commonly pyrite, and its precursors - mackinawite and greigite) produces excessive amounts of sulphuric acid (VI), which cannot be neutralized due to the weak buffer soil capacity. As shown in Figure 3, the field $\mathrm{pH}$ of the studied soils $\left(\mathrm{pH}_{\mathrm{a}}\right)$ in their undisturbed state was neutral or slightly alkaline, but after exposition of many soil samples to air in the laboratory $\left(\mathrm{pH}_{\mathrm{ox}}\right)$ or treatment with peroxide $\left(\mathrm{pH}_{\text {pox }}\right)$ marked drops in $\mathrm{pH}$ were recorded (Hulisz 2013). This effect was primarily observed in poorly-aerated soils developed from marine-alluvial sediments characterized by low
$\mathrm{rH}$ (index of the reducing power of a redox system) and $\mathrm{C}: \mathrm{S}$ values (Fig. 3, Table 1). The $\mathrm{pH}_{\text {ox }}$ values decreased below 4.0 and $\mathrm{pH}_{\text {pox }}$ below 2.5, which means that these soils can be identified as potential acid sulphate soils (Dent 1986, Urbańska et al. 2012) (Table 1).

The salt content in the soils studied by Hulisz (2013) undoubtedly reflected the brackish nature of the Baltic Sea. However, there were more factors controlling soil salinity and sodicity: distance from the water line, frequency of seawater flooding, impact of fresh water, the microrelief and lithology of the base sediment, and human activity (hydrotechnical infrastructure) - Hulisz 2013. Thus, the electrical 


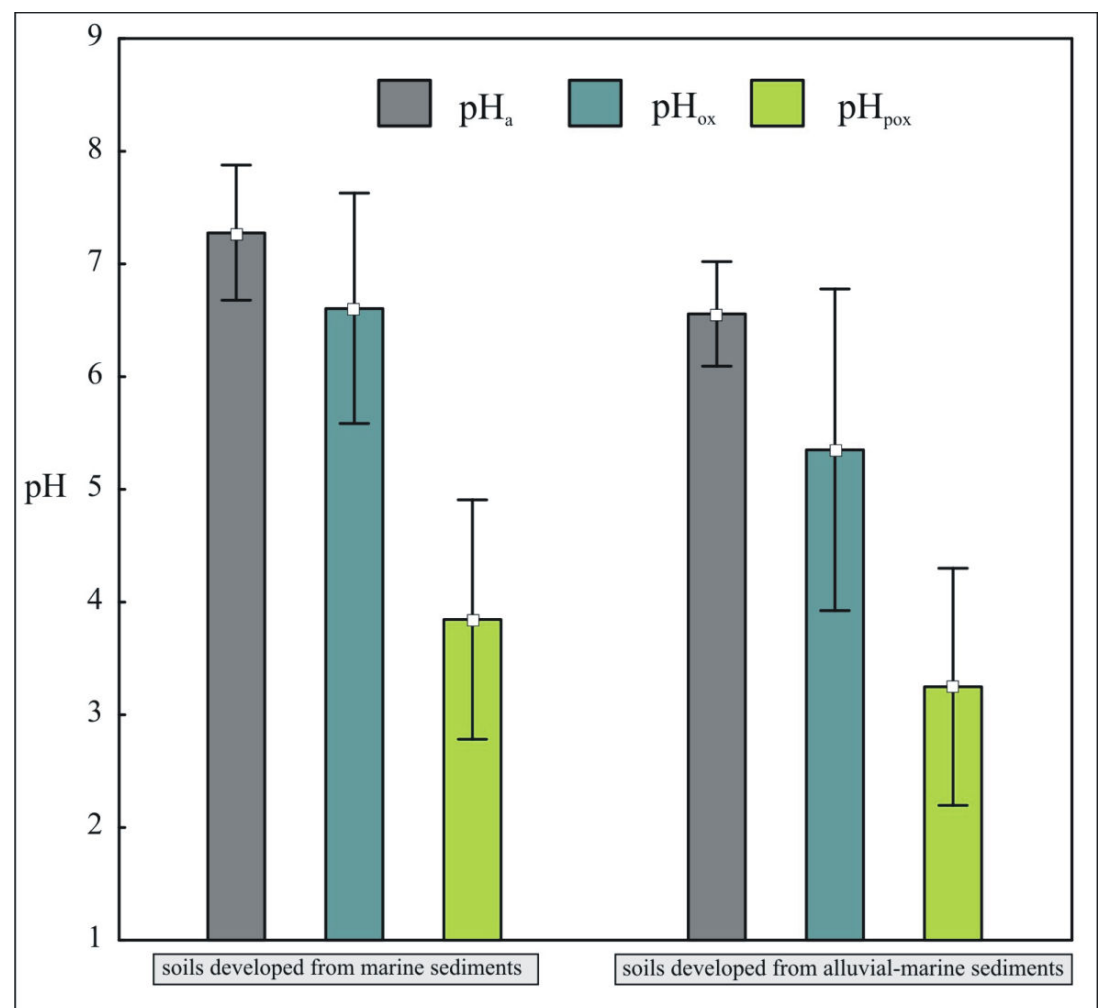

FIGURE 3. Susceptibility to acidification of Polish coastal marsh soils based on results by Hulisz (2013): Explanations of symbols: $\mathrm{pH}_{\mathrm{a}}-\mathrm{pH}$ measurement in the field, $\mathrm{pH}_{\mathrm{ox}}-\mathrm{pH}$ measurement after incubation of soil samples under laboratory conditions within two months, $\mathrm{pH}_{\mathrm{pox}}-\mathrm{pH}$ measurement after oxidation with $30 \% \mathrm{H}_{2} \mathrm{O}_{2}$

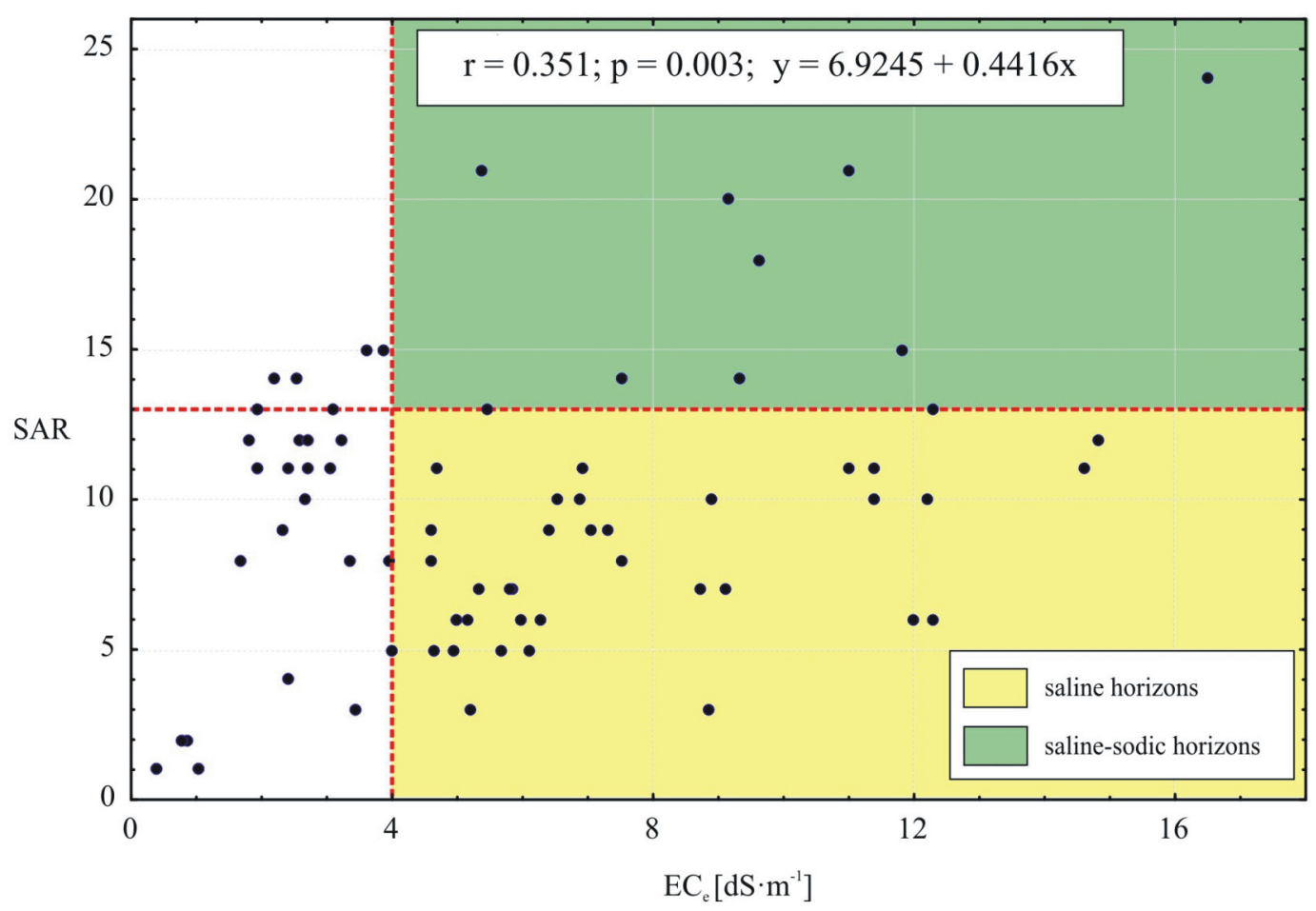

FIGURE 4. Salinity and sodicity level in Polish coastal marsh soils based on results by Hulisz (2013). Explanations of symbols: $\mathrm{EC}_{\mathrm{e}}$ - electrical conductivity of saturated paste extracts, SAR - sodium adsorption ratio of the saturated soil-paste extract 
TABLE 2. Characteristics of marsh soils in previous editions of Polish soil classifications

\begin{tabular}{lll}
\hline Edition, year & Taxonomic range & Description \\
\hline I, 1956 & No marsh soils unit & \\
\hline II, 1959 & No marsh soils unit & \\
\hline III, 1974 & Class: Alluvial and colluvial soils & - limited occurrence, mostly agricultural lands, \\
& Type: Marsh soils & - development from layered sea sediments in areas subjected to seawater \\
& (Marsh alluvial soils) & flooding, \\
& & - specific colloidal-chemical and physical properties and, particularly, \\
& & a considerable saturation with Ca and Na ions, \\
& & - presence of shell fragments in the soil profile. \\
\hline IV, 1989 & Division: Alluvial and colluvial soil & - very small areas along the coast, polder of the Żulawy including part of the \\
& Order: Alluvial soilss & Vistula Lagoon, \\
& Type: Marsh alluvial soils & - formation in layered marine sediments, \\
& & - specific composition of the sorption complex (saturated with Ca and \\
& & Na ions) affected the physical properties, \\
& & no subtypes due to small area and poor identification of soil properties. \\
\hline V, 2011 & No marsh soils unit & \\
\hline
\end{tabular}

conductivity of saturated paste and sodium adsorption ratio varied widely $\left(\mathrm{EC}_{\mathrm{e}} 0.4-16.5 \mathrm{dS} \cdot \mathrm{m}^{-1}\right.$, SAR 124; Table 1, Fig. 4; Hulisz 2013). The differential effect of seawater was also confirmed by the equivalent $\mathrm{Mg}: \mathrm{Ca}$ ratio in the range from 0.2 to 3.9 (Pracz and Kwasowski 2005). According to the U.S. Salinity Laboratory Staff classification system (Richards 1954), most of the studied soils may be described as saline or saline-sodic (Fig. 4).

\section{COASTAL MARSH SOILS IN THE POLISH SOIL CLASSIFICATION: HISTORY AND TERMINOLOGY}

The first description of marsh (marsh alluvial) soils was included in the legend of a 1:100,000 scale map (Musierowicz 1954). They were distinguished in the group of alluvial soils (in Polish: mady) in four variants, depending on the solum thickness: very shallow $(0-25 \mathrm{~cm})$, shallow $(25-50 \mathrm{~cm})$, medium deep $(50$ $100 \mathrm{~cm})$ and deep $(>100 \mathrm{~cm})$. Despite the existence of the above-mentioned soil map unit, marsh soils were omitted in the first two editions of the Polish soil classification: A Natural and Genetical Classification of Polish Soils (1956) and Genetical Classification of Polish Soils (1959). In the next two editions they were involved in the class (Polish Soil Classification 1974) or the order (Polish Soil Classification 1989) of alluvial soils in the rank of a soil type (Table 2).

Marsh soils have not been distinguished in the current edition of the Polish Soil Classification (2011), probably due to their minor importance and the lack of contemporary data (Table 1). Regardless of this fact, it is possible to identify the stratified marine sediments as a fluvic soil diagnostic material (Polish
Soil Classification 2011). It refers to fluviatile, marine and lacustrine sediments that receive fresh material at regular intervals or have received it in the recent past.

The term "alluvial" is traditionally most closely associated with the soils of river valleys (Miklaszewski 1912). Therefore, in the author's opinion, it was inappropriately used for soils developed from marine deposits (Polish Soil Classification 1974, 1989, Table 2). The alluvium (from the Latin alluvium, alluere, washed against) is commonly defined as material deposited by flowing water, as in a riverbed, flood plain, or delta (Reineck and Singh 1986). Considering all the above facts, it seems appropriate that this term be used only for soils formed in both marine- and riverine-influenced environments, e.g. the lower delta plains.

\section{SUGGESTIONS FOR CLASSIFICATION OF THE COASTAL MARSH SOILS IN POLAND}

Based on the above considerations regarding marsh soils, it seems reasonable to introduce some additions to the Polish Soil Classification (2011). The comprehensive proposal was developed by Hulisz (2013). It concerned the restoration of the marsh soil unit in full accordance with the quantitative-genetic approach used in the fifth edition. This proposal took into account both the current classification rules and close taxonomic relations between marsh and alluvial soils. The author modified and extended the concept included in previous editions of the Polish Soil Classification $(1974,1989)$ with the suggested introduction of a new soil type - marsh soils (in Polish: marsze; SM) - in the order of weakly-developed soils (S). Three subtypes: brackish marsh soils (in 
Polish: marsze słonawe - SMb), sulphate brackish marsh soils (in Polish: marsze słonawe zasiarczone $\mathrm{SMbz}$ ) and sodic marsh soils (in Polish: marsze sodowe - SMs) should be distinguished within this type. Similarly to alluvial soils, the marsh soils should be identified by the presence of the fluvic diagnostic material. Furthermore, some coastal plain soils in the initial stage of development could be included in the type "accumulative initial soils" (IJ).

However, this proposal may be not optimal in the context of a substantial modification of the Polish classification system, e.g. by the introduction of completely quantitative hierarchical key (Kabała 2014). With this approach, the question arises which of the features commonly found in the marsh soils should have a higher taxonomic priority, stratification (fluvic material) or gleying? Undoubtedly, the formation of these soils in very dynamic coastal zone is closely related to the impact of both surface and ground water. Therefore, a common feature of these soils (if not artificially drained) is strong expressed gleying, which means that they can also meet the diagnostic criteria for gleysols (in Polish: gleby glejowe). To investigate this question, it is worth following a major change which clearly affected the classification of coastal marsh soils in the World Reference Base For Soil Resources 2014 update 2015 (IUSS Working Group WRB 2015). In comparison with the previous version of WRB (IUSS Working Group WRB 2007), the definition of Gleysols has been broadened and Fluvisols were moved down in the key to be the second-to-last Reference Soil Group. As a result, the majority of the marsh soils previously characterized as Fluvisols with strong gleyic properties and other features expressed through the qualifiers Hypersalic, Hyposalic, Thaptohistic, Protothionic, Sodic, Hyposodic (Hulisz 2013) are now classified as Fluvic Gleysols. In this way, the Fluvisols reference group comprises only weakly gleyed soils, which meet the criteria for the fluvic diagnostic material. According to Schad (2016), this change gives soil properties (e.g. salinity, redox) precedence over their mere position in the landscape. In the author's opinion, the adoption of a similar solution could help to organize the classification of soils with varying degree of gleying in the Polish system. But it should be noted that this concept is not in line with the Polish traditional genetic approach and hence it can be controversial. As a consequence, the significant changes within units of soils affected by the processes of gleying (alluvial, mucky and colluvial soils, black earths, etc.) would be necessary. Similar suggestions regarding colluvial soils were recently given by Świtoniak (2014).
Moreover, it is particularly important to give an adequate rank for saline, sodic and acid sulphate soil materials, e.g. referring to solutions used in the WRB system. This problem also relates to the classification of other Polish soils with these properties, and therefore requires broader discussion (Hulisz 2007, Hulisz et al. 2011, Uzarowicz and Skiba 2011).

\section{CONCLUDING REMARKS}

The specific environmental conditions of the Polish coastal zone favour the formation of marsh soils at only certain locations, such as coastal plains with estuaries, lagoons or deltas. The marsh soils form on the boundary between marine and terrestrial environments with a strong influence of geogenetic factors (geo-pedogenesis). Therefore, such soils have unique geochemical characteristics which set them apart from typical alluvial soils. In addition, like gleysols, the marsh soils may show strong gleying.

The author believes that presented data can contribute to a better understanding soil forming processes occurring in the Polish coastal zone. However, it should be emphasized that the developing appropriate taxa for these unique soils needs a compromise between genetic and quantitative approaches.

\section{ACKNOWLEDGMENTS}

The author wishes to thank Prof. Renata Bednarek and Prof. Urszula Pokojska for stimulating discussion and valuable comments. This study was financed by the Polish Ministry of Science and Higher Education (grant N N305 231135, 2008-2011).

\section{REFERENCES}

A Natural and Genetical Classification of Polish Soils (Przyrodniczo-genetyczna klasyfikacja gleb Polski), 1956. Roczniki Nauk Rolniczych 74, seria D: 1-96 (in Polish with English summary).

Ad-hoc-Arbeitsgruppe Boden, 2005. Bodenkundliche Kartieranleitung. Bundesanstalt für Geowissenschaften und Rohstoffe in Zusammenarbeit mit den Staatlichen Geologischen Diensten, Hannover: 1-438 (in German).

Andriesse W., Van Mensvoort M.E.F., 2006. Acid sulfate soils: Distribution and extent. [In:] Encyclopedia of Soil Science. Taylor and Francis, New York: 14-28.

Baranowski A., 1962. The soil properties of Marzęcino, the youngest polder of the Vistula delta (Właściwości gleb Marzęcina, najmłodszego polderu delty Wisły). Roczniki Gleboznawcze Soil Science Annual 11: 117-145 (in Polish with English abstract).

Dąbkowska-Naskręt H., 1990. The composition and physico-chemical properties of selected alluvial soils from the Lower 
Vistula Valley, with regard to their diagnostic features (Skład i właściwości fizykochemiczne wybranych gleb aluwialnych Doliny Dolnej Wisły z uwzględnieniem ich cech diagnostycznych). Rozprawy 38, ATR, Bydgoszcz (in Polish with English summary).

Dent D., 1986. Acid sulphate soils: a baseline for research and development. ILRI Publ. 39. International Institute for Land Reclamation and Improvement, Wageningen.

Dijkema K.S., 1990. Salt and brackish marshes around the Baltic Sea and adjacent parts of the North Sea: their vegetation and management. Biological Conservation 51: 191-209.

Genetical Classification of Polish Soils (Genetyczna klasyfikacja gleb Polski), 1959. Roczniki Gleboznawcze - Soil Science Annual 7(2): 1-103 (in Polish with English summary).

Giani L., 1992. Entwicklung und Eigenschaften von Marschböden im Deichvorland der südlichen Nordseeküste. Habilitationsschrift. Oldenburg (in German).

Huckle J.M., Marrs R.H., Potter J.A., 2004. Spatial and temporal changes in salt marsh distribution in the Dee estuary, NW England, determined from aerial photographs. Wetlands Ecology Management 12: 483-489.

Hulisz P., 2007. Proposals of systematics of salt-affected soils in Poland (Propozycje systematyki gleb zasolonych występujących w Polsce). Roczniki Gleboznawcze - Soil Science Annual 63(1/2): 121-129 (in Polish with English abstract).

Hulisz P., 2013. Genesis, properties and systematics position of the brackish marsh soils in the Baltic coastal zone (Geneza, właściwości i pozycja systematyczna marszy brakicznych w strefie oddziaływania wód Bałtyku). Rozprawy habilitacyjne. Wyd. UMK: 137 pp. (in Polish with English summary).

Hulisz P., 2014. Flat coastal plan of the Hel Peninsula (Puck Lagoon, Poland). [In:] Soil Sequences Atlas (Świtoniak M., Charzyński P., Editors). Nicolaus Copernicus University Press, Toruń: 37-46.

Hulisz P., Kwasowski W., Malinowski R., 2011. Properties and taxonomic position of soils affected by salinization and sulphurization in Poland (Właściwości i ranga systematyczna gleb objętych wpływem procesów zasolenia i zasiarczenia w Polsce). $28^{\text {th }}$ Congress of the Polish Society of Soil Science "Soil - Human - Environment", Toruń: 58.

Hulisz P., Krześlak I., Karasiewicz T., 2012. Characteristics of sedimentary environments in brackish marsh soils in relation to organic matter properties (Puck Lagoon, Northern Poland). Ecological Questions 16: 87-97.

Hulisz P., Gonet S.S., Giani L., Markiewicz M., 2013. Chronosequential alterations in soil organic matter during initial development of coastal salt marsh soils at the southern North Sea. Zeitschrift für Geomorphologie 57(4): 515-529.

Hulisz P., Michalski A., Dąbrowski M., Kusza G., Łęczyński L., 2015. Human-induced changes in the soil cover at the mouth of the Vistula River Cross-Cut (northern Poland). Soil Science Annual 66(2): 67-74.

IUSS Working Group WRB, 2007. World Reference Base for Soil Resources 2006, first update 2007. World Soil Resources Reports No. 103. FAO, Rome.

IUSS Working Group WRB, 2015. World Reference Base for Soil Resources 2014, update 2015 International soil classification system for naming soils and creating legends for soil maps. World Soil Resources Reports No. 106. FAO, Rome.

Kabała C., 2014. Classification of Polish Soils - current state and further development (Systematyka gleb Polski - stan aktualny i dalszy rozwój). Soil Science Annual 65(2): 91-98 (in Polish with English abstract).

Kostrzewski A., Musielak S., 2008. Contemporary relief evolution of the southern Baltic Sea coast (Współczesna ewolucja rzeźby wybrzeża południowego Bałtyku). [In:] Współczesne przemiany rzeźby Polski (Starkel L., Kostrzewski A., Kotarba A, Krzemień K., Editors). SGP, IGiGP UJ, IG i PZ PAN, Kraków: 327-348 (in Polish).

Krzyszowski J., 1952. Soils of the Żuławy and adjacent terrains (Gleby Żuław i terenów przyległych). Roczniki Gleboznawcze - Soil Science Annual 2: 92-111 (in Polish with English abstract).

Kwasowski W., 1999. Characteristics of the sulphide and acid sulphate soils in the areas of the Puck Lagoon and Mrzeżyno (Charakterystyka gleb siarczkowych i kwaśnych siarczanowych rejonu Zatoki Puckiej i okolic Mrzeżyna). Manuscript of PhD thesis. SGGW, Warsaw (in Polish).

Malinowski R., 2012. Flood plain soils of the estuary valley of the Warta river and the lower Oder river valley and their transformations as a result of hydrotechnical operations and farming activity (Gleby tarasu zalewowego doliny ujścia Warty i doliny dolnej Odry oraz ich przekształcenia w wyniku zabiegów hydrotechnicznych i użytkowania rolniczego). Wyd. Uczelniane Zachodniopomorskiego Uniwersytetu Technologicznego, Szczecin: 1-188 (in Polish with English abstract).

Michalski A., 2015. Anthropogenic transformations in the rightbank floodplain soil cover on the Pędzewo-Czarnowo stretch of the Vistula River (Antropogeniczne przekształcenia pokrywy glebowej prawobrzeżnej równiny zalewowej Wisły na odcinku Pędzewo-Czarnowo). Manuscript of PhD thesis. UMK Toruń (in Polish).

Miklaszewski S., 1912. Soils of the Polish territories taking into particular account the Kingdom of Poland (Gleby Ziem Polskich ze szczególnym uwzględnieniem Królestwa Polskiego). $2^{\text {nd }}$ edition, Warsaw: 1-232 (in Polish).

Musierowicz A., 1954. A classification of Polish soils by the Polish Soil Science Society. (Klasyfikacja gleb Polski ustalona przez Polskie Towarzystwo Gleboznawcze). Roczniki Gleboznawcze - Soil Science Annual 3: 3-24 (in Polish with English abstract).

Niedźwiecki E., Protasowicki M., Czyż H., Wojcieszczuk T., Malinowski R., 2002. Chemical properties of Karsiborska Kępa Island's strongly-acidic soils influenced by riverinemarine waters (Właściwości silnie zakwaszonych gleb Karsiborskiej Kępy, znajdujących się pod oddziaływaniem wód rzeczno-morskich). Zeszyty Problemowe Postępów Nauk Rolniczych 482: 397-402 (in Polish with English abstract).

Polish Soil Classification (Systematyka gleb Polski), 1974. Roczniki Gleboznawcze - Soil Science Annual 25: 1-148 (in Polish with English abstract).

Polish Soil Classification (Systematyka gleb Polski), 1989. Systematyka gleb Polski. Roczniki Gleboznawcze - Soil Science Annual 40(3/4): 1-150 (in Polish with English abstract).

Polish Soil Classification (Systematyka gleb Polski), 2011. Roczniki Gleboznawcze - Soil Science Annual 62(3): 1-193 (in Polish with English abstract).

Pracz J., 1989. Properties of soils formed under the influence of saline ground water in the region of the Polish Baltic coast. Rozprawy naukowe i monografie. Wyd. SGGW-AR, Warszawa (in Polish with English abstract): 1-91.

Pracz J., Kwasowski W., 2005. Organic saline soils from the area of the Puck Bay (Organiczne gleby słone występujące w rejo- 
nie Zatoki Puckiej). Roczniki Gleboznawcze - Soil Science Annual 56(3/4): 89-99 (in Polish with English abstract).

Prusinkiewicz Z., 1971. Cliff naspas - a new type of marine coast soils (Naspy przyklifowe - nowy typ gleb morskiego pobrzeża). Zeszyty Naukowe UMK, Geografia 26(8): 133157 (in Polish with English abstract).

Reineck H.E., Singh I.B., 1986. Depositional sedimentary environments. Springer Verlag, New York-Heidelberg-Berlin.

Richards L.A., 1954. Diagnosis and improvement of saline and alkali soils. Agriculture Handbook 60, USDA, Washington.

Schad P., 2016. The International Soil Classification System WRB, Third Edition, 2014. [In:] Novel methods for monitoring and managing land and water resources in Siberia (Mueller L., Sheudshen A.K., Eulenstein F., Editors). Springer Water: 563-571.

Schroeder D., Brümmer G., 1969. Beitrage zur Genese und Klassifizierung der Marschen. Zeitschrift für Pflanzenernährung und Bodenkunde 122(3): 228-249 (in German).

Shlyakhov S.A., Kostenkov N.M., 1999. Chemical and physicochemical properties of plain soils in the Pacific coast of Russia. Eurasian Soil Science 32(9): 974-983.

Świtoniak M., 2014. Issues relating to classification of colluvial soils in young morainic areas (Chełmno and Brodnica Lake District, northern Poland). Soil Science Annual 66(2): 57-66.
Thayer G.W., McTigue T.A., Bellmer R.J., Burrows F.M., Merkey D.H., Nickens A.D., Lozano S.J., Gayaldo P.F., Polmateer P.J., Pinit P.T., 2003. Science-based restoration monitoring of coastal habitats, Volume one: A framework for monitoring plans under the Estuaries and Clean Waters Act of 2000 (Public Law 160-457). NOAA Coastal Ocean Program Decision Analysis Series No. 23, Volume 1. NOAA National Centers for Coastal Ocean Science, Silver Spring, MD: 1-98.

Urbańska E., Hulisz P., Bednarek R., 2012. Effect of sulphide oxidation on selected soil properties. Journal of Elementology 17(3): 505-515.

Uzarowicz Ł., Skiba S., 2011. Technogenic soils developed on mine spoils containing iron sulphides: Mineral transformations as an indicator of pedogenesis. Geoderma 163(1-2), 95-108.

Van der Graaf A.J., Stahl J., Veeneklaas R.M., 2007. Vegetation characteristics of a brackish marsh on Gotland and foraging choices of migrating and brood rearing geese. Annales Botanici Fennici 44: 33-41.

Witek J., 1965. Soils of the Żuławy Wiślane (Gleby Żuław Wiślanych). Pamiętnik Puławski, Prace IUNG 18: 157-266 (in Polish with English abstract).

Received: April 13, 2016

Accepted: June 1, 2016

\section{Marsze w polskiej strefie przybrzeżnej: charakterystyka i problemy klasyfikacji tych gleb}

Streszczenie: W pracy przedstawiono najnowszy stan wiedzy dotyczący genezy, właściwości i rangi taksonomicznej marszy gleb wytworzonych z osadów morskich lub rzeczno-morskich. Zajmują one niewielki areał i występują punktowo wzdłuż wybrzeża polskiego Bałtyku (równiny nadbrzeżne, delty rzek). Gleby te należą wciąż do najsłabiej rozpoznanych w naszym kraju i dlatego też zapewne zostały pominięte w piątej edycji Systematyki gleb Polski (2011). Badania autora wykazały, że marsze powstają w środowisku lądowo-morskim, przy wyraźnej dominacji procesów geogenetycznych (geo-pedogeneza). W związku z tym mają one unikatowe cechy morfologiczne i właściwości, które wskazują na wyraźną odrębność typologiczną tych gleb, szczególnie w porównaniu z typowymi madami rzecznymi. Sugeruje to niewątpliwie konieczność uaktualnienia polskiego systemu klasyfikacji gleb. Zaproponowano wprowadzenie nowego typu - marszy (SM) do rzędu gleb słabo ukształtowanych (S) oraz trzech podtypów: marszy słonawych (SMb), marszy słonawych zasiarczonych (SMbz) i marszy sodowych (SMs). Ponadto niektóre gleby równin nadbrzeżnych, charakteryzujące się początkowym stadium rozwoju, mogłyby być włączone do typu gleb inicjalnych akumulacyjnych (IJ). Oprócz tego przedstawiono także sugestie zmian dotyczących terminologii oraz nadania odpowiedniej rangi taksonomicznej cechom zasolenia i zasiarczenia. Propozycja klasyfikacji marszy jest w pełni kompatybilna z ilościowo-genetycznym podejściem zastosowanym w Systematyce gleb Polski (2011). Jednak przy założeniu powstania w niedalekiej przyszłości hierarchicznego klucza ilościowego, ze względu na bliskie relacje taksonomiczne pomiędzy marszami (również madami) a glebami glejowymi, może ona nie być optymalna. W związku z tym poddano także dyskusji pozycję systematyczną marszy w kontekście definicji gleb glejowych, nawiązując do rozwiązań przyjętych w obecnej edycji międzynarodowej klasyfikacji World Reference Base for Soil Resources (2015).

Słowa kluczowe: marsze, Morze Bałtyckie, mady morskie, Systematyka gleb Polski, WRB 